\title{
Mantra Tolak Bala Komunitas Dayak Kalimantan Barat: Kajian Semiotik Riffaterre
}

\author{
Sesilia Seli \\ Program Studi Pendidikan Bahasa Indonesia, Fakultas Keguruan dan Ilmu Pendididkan, Universitas Tanjungpura \\ Jl. Prof. Dr. H. Hadari Nawawi, Pontianak, Kalimantan Barat, 78124, Indonesia \\ Corresponding author: sesilia.seli@fkip.untan.ac.id \\ Telepon: 081348128985
}

\begin{abstract}
The biggest motivation for researching the Tolak Bala Mantra of the Dayak community is based on the phenomenon that the mantra is still alive and is used as a means of communication in dealing with and interpreting every life event they experience. This study aims to describe the results of the analysis and interpretation of the Tolak Bala Mantra meaning through heuristic and hermeneutic readings; matrices and models in the Tolak Bala Mantra; and the hypnogram in the Tolak Bala Mantra of the West Kalimantan Dayak community. This study uses a qualitative descriptive method and Riffaterre's semiotic approach. The results of the study show that heuristically and hermeneutically, the meaning of the Tolak Bala Mantra contains a request to God so that people are protected from COVID-19, disasters, calamities, and bad things that interfere with human life. The matrix is not present directly in the text of the mantra, the model appears as the actualization of the matrix, and the meaning of the mantra is focused through the determination of the model. The hypnogram in this mantra is a potential hypnogram based on the fact that the use of the Tolak Bala Mantra has become a sacred and hereditary ritual that they believe in and believe can protect them from the threat of danger, calamity, and illness including COVID-19. The Tolak Bala Mantra is a communication medium to ward off spirits that bring disease, disaster, or catastrophe. Keywords: Dayak of The West Kalimantan; Riffaterre's Semiotics; Tolak Bala Mantra
\end{abstract}

\begin{abstract}
Abstrak
Motivasi terbesar untuk meneliti mantra tolak bala komunitas Dayak didasarkan pada fenomena bahwa mantra tersebut masih hidup dan digunakan sebagai sarana komunikasi dalam menghadapi dan memaknai setiap peristiwa hidup yang mereka alami. Penelitian ini bertujuan untuk mendeskripsikan hasil analisis dan interpretasi terhadap makna mantra tolak bala melalui pembacaan heuristik dan hermeneutik; matrik dan model dalam mantra tolak bala; dan hipogram dalam mantra tolak bala komunitas Dayak Kalimantan Barat. Penelitian ini menggunakan metode deskriptif kualitatif dan pendekatan semiotik Riffaterre. Hasil penelitian menunjukkan bahwa secara heuristik dan hermeneutik, makna mantra tolak bala berisi permohonan kepada Tuhan agar masyarakat terhindar dari COVID-19, bencana, malapetaka, dan hal-hal buruk yang menggangu kehidupan manusia. Matriks tidak hadir secara langsung dalam teks mantra, model tampil sebagai aktualisasi matriks, dan makna mantra terfokus melalui penetuan model. Hipogram dalam mantra ini merupakan hipogram potensial yang didasarkan pada realita bahwa penggunaan mantra tolak bala telah menjadi ritual yang sakral dan turun-temurun yang mereka yakini dan percayai dapat melindungi mereka dari ancaman marabahaya, malapetaka, dan sakit-penyakit termasuk COVID-19. Mantra tolak bala berfungsi sebagai media komunikasi untuk mengusir makhluk halus yang mendatangkan penyakit, bencana, atau malapetaka.
\end{abstract} Kata kunci: Dayak Kalimantan Barat; Mantra Tolak Bala; Semiotik Riffaterre

\section{Pendahuluan}

Pandemi COVID-19 merupakan masalah terbesar yang memengaruhi seluruh aspek kehidupan manusia di seantero dunia pada abad ini. Banyak manusia yang terinfeksi virus ini, bahkan ribuan orang meninggal dunia. Kehadiran COVID-19 telah mengubah banyak hal, termasuk mengubah perilaku manusia dalam menyikapi ancaman virus tersebut, tidak terkecuali masyarakat Dayak. Banyak cara yang dilakukan, mulai dari menjaga stamina tubuh dengan makanan yang bergizi dan mengonsumsi vitamin, berolah raga, membiasakan hidup bersih, membatasi diri untuk keluar rumah, hingga menjaga jarak.

Bagi komunitas Dayak, pandemi COVID-19 telah menggugah dan membawa mereka kembali pada kearifan lokal yang mereka miliki, yang 
selama ini seperti ditelantarkan. Masyarakat Dayak memiliki warisan budaya berupa kearifan lokal dalam hal menjaga dan melindungi seluruh warga kampung terhadap berbagai penyakit, sampar, petaka, dan marabahaya. Kearifan lokal tersebut dikenal dengan ritual tolak bala. Selama ini ada beberapa daerah yang masih konsisten melakukan ritual tersebut, namun sebagian besar komunitas Dayak di Kalimantan Barat tidak melakukannya lagi. Ancaman virus COVID-19 secara religiositas telah menggerakkan komunitas Dayak di Kalimantan Barat untuk menggunakan ritual tolak bala sebagai satu di antara cara untuk memerangi virus COVID-19 yang mengancam hidup manusia. Ritual tersebut dilakukan hampir bersamaan di setiap wilayah sesuai dengan adat-istiadat yang mereka miliki, yang tentu saja memiliki kemiripan sekaligus juga perbedaan sebagai akibat banyaknya jumlah subsuku dalam komunitas Dayak.

Dengan dilakukannya ritual tolak bala, komunitas Dayak berpantang dan mengurung diri di rumah masing-masing yang secara modern dikenal dengan istilah pembatasan sosial (social distancing) dan pembatasan jarak (physical distancing). Jauh sebelum dikenal kedua istilah tersebut, komunitas Dayak telah mengenalnya dan melakukannya dengan berbagai istilah, seperti balala' (istilah Dayak Kanayatn), dan lain sebagainya.

Dalam penelitiannya, Chofeer and Darmawan (2021) melaporkan bahwa komunitas Dayak (Dayak Desa Umin) memercayai dan meyakini bahwa tradisi tolak bala dapat membantu mereka mengatasi kesulitan, bahaya, gangguan, baik dari alam maupun makhluk-makhluk yang tak terlihat bahkan sakit dan pandemi COVID-19.

Pada saat ritual tolak bala dilaksanakan, pemantra membacakan mantra (doa) sebagai sarana untuk berkomunikasi dengan Pencipta agar kampung mereka terhindar dari wabah penyakit dan malapetaka. Mereka percaya dengan ritual dan mantra tersebut mereka akan terhindar dari wabah penyakit, petaka, dan hal-hal buruk yang mengganggu kampung dan kehidupan mereka.
Berdasarkan hasil wawancara dengan pemantra, ternyata mantra tolak bala tidak hanya digunakan untuk mengusir penyakit, tetapi dapat digunakan dalam berbagai aktivitas masyarakat yang tujuannya untuk mendapat perlindungan dan terhindar dari berbagai malapetaka. Tujuannya menjauhkan manusia dari hal buruk yang dapat saja mengancam kehidupan mereka. Dalam penelitian ini diperoleh tiga buah mantra yang terkategori sebagai mantra tolak bala dari tiga subsuku Dayak di Kabupaten Sanggau dan Ketapang. Ketiga buah mantra tersebut menjadi korpus kajian dalam penelitian ini.

Dayak adalah nama suku (orang asli) yang mendiami pulau Kalimantan (Frelians dan Perbawaningsih 2020). Menurut Rousseau (1990); Riwut (1993); Muhrotien (2012); dan Darmadi (2016), terdapat 300-405 subsuku Dayak. Para ahli mengelompokkan suku-suku Dayak di Pulau Kalimantan berdasarkan aspek budaya, misalnya hukum adat, ritual-ritual, bahasa, wilayah geografi, dan sebagainya. Mallinskrot (Alloy et al, 2008) membagi suku Dayak berdasarkan hukum adat ke dalam enam rumpun yang disebutnya stammenras, yaitu: (1) Kenyah-Kayaan, Bahau; (2) Ot Danum; (3) Klemantan; (4) Murut; (5) Iban; dan (6) Punan. Menurut Hamjen (2015), ada tujuh rumpun suku Dayak yang ada di Pulau Kalimantan, yakni Dayak Ngaju, Dayak Murut, Dayak Iban, Dayak Apo Kayan, Dayak Ot Danum, Dayak Punan, dan Dayak Klemantan.

Mantra tolak bala yang dijadikan objek kajian dalam penelitian ini merupakan mantra dari subsuku Dayak Kerambai, Dayak Hibun, dan Dayak Simpakan. Ketiga-tiganya berada di Provinsi Kalimantan Barat dan temasuk ke dalam rumpun Dayak Klemantan. Hamjen (2015) mengatakan bahwa Dayak Klemantan (Dayak Darat) mendiami daerah barat pulau Kalimantan. Rumpun Dayak ini tersebar di hulu-hulu sungai yang ada di Kalimantan Barat dan Sarawak, Malaysia. Dayak Darat di Malaysia yang dikenal dengan nama orang Bidayuh. Subsuku Dayak Darat adalah Dayak Kanayatn, Dayak Bidayuh, Dayak Ketungau, dan lain sebagainya. 
Suku Dayak Kerambai adalah sub suku Dayak yang bermukim di Kampung Nekan, Segirau, Engkahan, Pesing, Entinuh, Entubah, Raut Kayan, Mabah, Seka, Masa Selangai, dan Raut Muara. Bahasa yang mereka gunakan adalah bahasa Kerambai (Alloy et al, 2008). Dayak Hibun atau sering juga dikenal dengan istilah populernya "Dayak Ribun" adalah kelompok subsuku Dayak di Kabupaten Sanggau yang dapat dijumpai di Kecamatan Tayan Hulu, Parindu, Bonti, dan Kembayan. Wilayah penyebaran di empat kecamatan ini terdapat di 91 kampung (Alloy et al, 2008). Dayak Simpakng adalah subsuku Dayak yang bermukim di Kecamatan Simpang Hulu dan Simpang Dua, Kabupaten Ketapang, tepatnya di sepanjang daerah aliran Sungai Banjur, Semandang, Baram, dan Kualatn (Alloy et al, 2008).

Mantra tolak bala sebagai sastra lisan digunakan sebagai sarana komunikasi antara pemantra dengan Tuhan (Tompau, Penompa, Duata) maupun makhluk gaib lainnya agar orang atau komunitas yang minta didoakan dengan mantra tersebut terhindar dari sakit, musibah, maupun malapetaka. Oleh sebab itu keberadaannya sebagai bagian dari budaya lokal perlu dilestarikan. Hal ini sesuai dengan pendapat Hendro dan Setiawan (2021) yang mengatakan bahwa upaya pelestarian dan pengembangan nilai-nilai budaya lokal dilakukan agar memiliki nilai tambah.

Para ahli sastra umumnya sependapat bahwa bentuk awal puisi Indonesia adalah mantra (Taum, 2011). Mantra atau sastra lisan disebut juga oral literature (Andalas \& Sulistyorini 2017). Maksudnya, mantra dituturkan dan disebarluaskan secara lisan dan turun temurun dengan cara berguru. Umumnya, mantra diajarkan oleh orang yang mempunyai daya gaib dan kesaktian yang disebut dukun, bomoh, atau pawang.

Secara etimologis, arti kata mantra adalah berpikir atau melindungi; melindungi pikiran dari gangguan jahat (Hartata, 2010). Menurut Roy (2012), mantra digunakan untuk menjelaskan legenda yang berkaitan dengan ritual, yang keduaduanya diwariskan secara lisan dan turun-temurun.
Mantra merupakan gubahan bahasa yang diresapi oleh kepercayaan akan dunia gaib yang timbul sebagai hasil imanjinasi berdasarkan kepercayaan animisme yang menciptakan nuansa magis (Kosasih, 2012). Menurut Suwatno (2012) mantra dapat berbentuk wacana, syair, pantun, dan juga liris. Hidayatullah (2016) mengelompokkan mantra menjadi empat, yaitu berbentuk syair, berbentuk pantun, berbentuk liris dan berbentuk bebas.

Mantra berkembang dalam masyarakat primitif. Eksistensi mantra dalam masyarakat sangat bergantung pada tingkat kebutuhan masyarakat akan mantra tersebut (Hamidin, 2016). Mantra digunakan sebagai solusi untuk menghadapi berbagai masalah dalam kehidupan (Nugraha, 2015). Oleh sebab itu mantra bukan hanya bersifat estetis, tetapi juga bersifat pragmatik (Setiadi \& Firdaus, 2018). Menurut Nurjamilah (2015) mantra berfungsi untuk mencapai tujuan dari kegiatan yang bersifat magis. Mantra diyakini dapat membantu manusia dalam memecahkan masalah yang dihadapi, terutama yang tidak dapat dipecahkan secara logis (Soedjijono dkk., 2012).

Mantra merupakan teks suci (sacret text) dan merupakan hasil kontemplasi (Yelle, 2003). Karena itulah mantra diyakini bersifat sakral dan hanya pawang yang dianggap pantas untuk mengucapkannya. Pengucapannya pun harus disertai dengan ritual, misalnya asap dupa, duduk bersila, gerak tangan, ekspresi wajah, dan sebagainya. Sesaji atau bendabenda tertentu dapat mendukung kesakralan ritual yang dilakukan. Hanya dalam suasana seperti itulah mantra tersebut berkekuatan gaib.

Menurut Zoest (1993) semiotik adalah ilmu yang menyelidiki semua bentuk komunikasi yang berkaitan dengan makna tanda dan berdasarkan atas sistem tanda. Menurut Teeuw (1982) semiotik sebagai tindak komunikasi. Semiotics is the science of sign (Wardoyo, 2005. Dalam semiotik, ada dua prinsip yang harus diperhatikan, yaitu penanda (signifier) atau yang 
menandai dan petanda (signified) atau arti tanda. Ada tiga jenis tanda, yaitu ikon, indeks, dan simbol (Zoest, 1993). Ikon adalah tanda yang memperlihatkan adanya hubungan yang bersifat alamiah antara penanda dengan petandanya. Hubungan itu adalah hubungan persamaan. Indeks adalah tanda yang menunjukkan hubungan kausal (sebab-akibat) antara penanda dengan petandanya. Simbol adalah tanda yang tidak memiliki hubungan alamiah antara penanda dengan petandanya, melainkan hubungan yang arbitrer. Ketiga tanda tersebut merupakan peralatan semiotik yang fundamental.

Menurut Riffaterre (1978) pembacalah yang bertugas memberikan makna terhadap tandatanda yang terdapat pada karya sastra. Tanda akan bemakna setelah dilakukan pembacaan dan pemaknaan. Sesungguhnya transfer semiotik dari tanda ke tanda terjadi dalam pikiran pembaca melalui interpretasi. Menurut (Lantowa et al, 2017), tanda merupakan kesatuan dari suatu bentuk penanda (signifier) dengan sebuah ide atau penanda (signified).

Riffaterre (1978) menjelaskan ada empat prinsip dalam memaknai sebuah puisi dengan menggunakan pendekatan semiotik yang meliputi ketidaklangsungan ekspresi; pembacaan heuristik dan hermeneutik; matriks dan model; dan hubungan intertekstual. Pembacaan heuristik dan hermeneutik merupakan langkah pertama untuk menenukan makna. Pembacaan heuristik dinamakan pembacaan tingkat pertama, yaitu memahami makna secara linguistik, yang disebut Ratih (2016) sebagai pembacaan dalam taraf mimesis. Menurut Diana (2018) pembacaan hermeneutik merupakan pembacaan tingkat kedua yang disebut juga pembacaan retroaktif, yaitu pembacaan berdasarkan konvensi sastra yang bertujuan untuk menginterpretasi makna secara utuh. Pembacaan heuristik didasarkan pada konvensi bahasa yang bersifat mimetic (tiruan alam) dan membangun serangkaian arti yang heterogen, berserak-serakan atau tak gramatikal. Hal ini dapat terjadi karena kajian didasarkan pada pemahaman arti kebahasaan yang bersifat lugas atau berdasarkan arti denotatif dari suatu bahasa (Santoso, 2004).
Menurut Pradopo (2011) pembacaan heuristik sebagai pembacaan yang berdasarkan struktur bahasa atau berdasarkan konvensi sistem semiotik tingkat pertama, yaitu pembacaan berdasarkan tata bahasa normatif, morfologi, semantik, dan sintaksis. Pembacaan heuristik dilakukan dengan menggunakan kode bahasa yang bersifat referensial (Faruk, 2012). Ratih (2016) mengatakan bahwa matriks merupakan konsep abstrak yang tidak pernah teraktualisasikan. Konsep ini dapat dirangkum dalam satu kata atau frase. Aktualisasi pertama dari matriks adalah model. Aktualisasi pertama itu berupa kata atau kalimat tertentu yang khas dan puitis. Kekhasan dan kepuitisan model itu mampu membedakan kata atau kalimatkalimat lain dalam puisi. Eksistensi kata itu dikatakan bila tanda bersifat hipogramatik dan karenanya monumental. Menurut Ratih (2013) matriks adalah kata hunci dari sebuah teks yang merupakan konsep abstrak yang tidak pernah teraktualisasi dan tidak muncul dalam teks. Matriks dapat berupa kata, frase, klausa, atau kalimat sederhana. Aktualisasi pertama dari matriks adalah model yang dapat berupa kata atau kalimat tertentu. Model ini kemudian diperluas menjadi varian-varian sehingga menurunkan teks secara keseluruhan.

Selain matriks, model dan varian, yang harus diperhatikan dalam memahami makna puisi (mantra) adalah hipogram. Hipogram adalah teks yang menjadi latar penciptaan sebuah teks baru. Hipogram merupakan landasan bagi penciptaan karya yang baru, mungkin dipatuhi, mungkin juga disimpangi oleh pengarang (Diana, 2018). Hiprogram terbagi dua, yakni hipogram potensial dan hipogram aktual (Riffaterre, 1978). Sebuah karya sastra dapat diberi makna secara hakiki dalam kontrasnya dengan hipogramnya (Teeuw, 1982).

Penelitian ini berkaitan dengan pemaknaan mantra tolak bala melalui pembacaan heuristik dan hermeneutik; penemuan matrik dan model dalam mantra tolak bala; dan penemuan hiprogram dalam ketiga mantra tolak bala yang 
dianalisis. Pendekatan yang digunakan adalah pendekatan semiotik Riffaterre. Penelitian ini bertujuan untuk mendeskripsikan hasil analisis dan interpretasi terhadap makna, matriks dan model, serta hipogram dalam mantra tolak bala suku Dayak di Kalimantan Barat. Selain itu, melalui penelitian ini dapat dilakukan perubahan cara pewarisan dari lisan ke bentuk tertulis yang dinilai mendesak untuk dilakukan, mengingat semakin sedikitnya penutur mantra. Penelitian ini dapat menjadi sarana dalam mengembangkan khazanah sastra daerah. Selain itu, hasil penelitian ini bermanfaat untuk menambah koleksi dan dokumen sastra daerah dalam bentuk puisi rakyat; teks kajian dalam mata kuliah Kajian Puisi, dan sumber rujukan bagi peneliti lain.

\section{Metode Penelitian}

Metode yang digunakan dalam penelitian ini adalah metode deskriptif. Dengan metode deskriptif, data penelitian dianalisis dan diuraikan menggunakan kata-kata atau kalimat dan bukan dalam bentuk angka-angka atau mengadakan perhitungan. Data penelitian ini diperoleh melalui kajian mendalam terhadap dokumen yang tersedia dalam bentuk cerita rakyat. Dalam hal ini metode deskriptif akan digunakan untuk mendeskripsikan atau menggambarkan gejala, peristiwa, kejadian, yang terdapat sewaktu penelitian dilakukan terhadap objek kajian. Data dalam penelitian deskriptif menurut Moleong (2017) berupa kata-kata, gambar, dan bukan angka-angka.

Bentuk penelitian ini adalah kualitatif, yaitu bentuk penelitian yang mengutamakan proses atau prosedur yang dijalankan, sedangkan hasilnya bergantung pada proses penelitian itu sendiri. Pendapat ini berdasar pada teori yang disampaikan oleh Bogdan dan Biklen, Lincoln dan Guba (Moleong, 2017).

Pendekatan yang digunakan dalam penelitian ini adalah pendekatan semiotik Riffaterre. Pendekatan semiotik digunakan untuk memaknai mantra tolak bala masyarakat
Dayak Kalimantan Barat. Pendekatan ini bertitik tolak pada pandangan bahwa bahasa mantra merupakan sistem tanda yang mengandung ketidaklangsungan ekspresi. Melalui pembacaan heuristik dan hermeneutik akan diungkap ketidaklangsungan ekspresi, matriks, model, dan hipogram dalam mantra tolak bala.

Sumber data penelitian adalah mantra tolak bala komunitas Dayak Kerambay, Dayak Hibun, dan komunitas Dayak Simpakng. Ketiga mantra tersebut masing-masing dituturkan oleh Nikolaus Tumbong (Dayak Keramba); Anna (Dayak Hibun); dan Redonius (Dayak Simpakng. Data penelitian berupa kata, frasa, dan kalimat yang menunjukkan makna, matriks dan model, serta hipogram dalam mantra tolak bala Dayak Kerambai, Dayak Hibun, dan Dayak Simpakng.

Teknik pengupulan data yang di-unakan teknik perekaman, wawancara, pentranskripsian, penyuntingan, penerjemahan, dan pendokumentasian. Instrumen dalam penelitian ini adalah peneliti sendiri sebagai instrumen kunci. Hal ini berlandas pada pendapat Bogdan dan Biklen, Lincoln dan Guba (Moleong, 2017). Penelitian kualitatif menjadikan manusia sebagai alat, artinya dalam penelitian kualitatif manusia (peneliti atau dengan batuan orang lain) bertindak sebagai instrumen atau alat utama baik dalam pengumpulan data, pencatatan data, maupun dalam menafsirkan data dengan mengerahkan kemampuan intelektual pengetahuan, dan keterampilan yang dimiliki terhadap fenomena yang ada. Untuk memudahkan pengumpulan data, peneliti menggunakan alat bantu penelitian yaitu alat perekam, pedoman wawancara, kamera, dan kartu pencatat data. Alat bantu tersebut memudahkan peneliti dalam mengumpulkan data supaya data yang diambil lengkap dan sesuai dengan fakta.

Pengujian keabsahan data dilakukan dengan ketekunan pengamatan dan triangulasi metode dan sumber. Teknik analisis data dilakukan secara deskriptif kualitatif dengan menggunakan pendekatan semiotik Riffaterre. 
Menurut Miles and Huberman (1994) aktivitas dalam analisis data kualitatif dilakukan secara interaktif dan berlangsung terus menerus sampai tuntas. Prosedur analisis data dimulai dari reduksi data, pemaparan data, dan penarikan penyimpulan. Pada tahap reduksi data dilakukan pengumpulan semua data yang berkaitan dengan pemaknaan, matrik dan model, serta hipogram. Setelah mereduksi data, tahap berikutnya adalah pemaparan hasil pemaknaan terhadap mantra tolak bala melalui pembacaan heuristik dan hermeneutik, matrik dan model, serta hipogram dalam mantra tolak bala. Selanjutnya dilakukan penyimpulan tentang analisis mantra tolak bala dengan menggunakan kajian semiotik Riffaterre.

\section{Hasil Penelitian dan Pembahasan}

\section{Pembacaan Heuristik dan Hermeneutik Mantra Tolak Bala Dayak Kerambai}

Hasil pembacaan secara heuristik dan hermeutik terhadap mantra tolak bala Dayak Kerambai menunjukkan bahwa komunitas ini menghaturkan permohonan kepada Tuhan melalui perantara pemantra (pepomang) agar mereka terhindar dari segala macam penyakit (khususnya COVID-19), malapetaka, marabahaya, dan bencana dengan menyerahkan diri secara penuh kepada penyelenggaraan ilahi seraya memohon ampun atas kesalahan yang telah dilakukan. Perhatikan kutipan mantra tolak bala Dayak Kerambai berikut ini. Omi dari Puleu borneo Kalimantan Barat mintau berkah ngajuk tompau de maha kuasa ngan kaseh sayang onak manusio de lebih paguh ngan taat sesamo adep. Kalau adeh berbuat niat tikat bulat da' kaye paguh omi wadunioti Mintau bodau layap bu'u maman ngajoh wappi'itn gansa saungan rimut ngan tanau ngan batuh ngan mao ngan na'angan kiyuh ngan ikat dungan (ikan adong) ngan jigeh binatak wadayeh. Omi mintau amput, mintau maaf dese baas neh nguse segala penyakit COVID-19. (Kami dari Pulau Borneo Kalimantan Barat minta berkat kepada Tuhan yang Maha Esa mohon belas kasih-Mu, kami anak manusia yang baik kepada sesama. Kalau ada perilaku dan perbuatan kami tidak baik di dunia ini, mohon lenyapkanlah ke dalam air, rimu, dan seisi air sungai kepiting, ikan-ikan, dan binatang yang ada di darat. Kami minta ampun, minta maaf, usirlah penyakit COVID-19). Hasil penelitian yang dilakukan Al Fikri, dkk. (2019) memiliki kemiripan dengan hasil penelitian ini berkenaan dengan makna yang diperoleh melalui pembacaan heuristik dan hermeneutik. Al Fikri dkk. menyimpulkan bahwa pembacaan mantra yang ditelitinya bertujuan untuk pengembalian sihir jahat kepada pemiliknya atas seizin Allah. Hal yang sama juga terjadi dalam pembacaan mantra tolak bala Dayak Kerambai yang bertujuan untuk mengembalikan segala macam penyakit ke tempat asalnya dengan pertolongan Tuhan agar tidak mengganggu kehidupan manusia.

Kata-kata ikonik yang ditemukan dalam mantra tolak bala ini adalah Tompau, bu'u, dan pulei Jalbelkab. Kata ikonis Tompau yang berarti "Tuhan" merupakan simbol yang bermakna pemberi kehidupan dan segala sesuatu di dunia ini adalah milik-Nya. Simbol ini menunjukkan bahwa pemantra menyerahkan segalanya kepada Tuhan agar mereka terhindar dari penyakit yang membahayakan. Perhatikan kutipan berikut.

Tabi'i Tompau Babuk, Tompau Tayuk,

Tompau Omang, Tompau Oyang ... Tabi'i tompau togih mula jaji dunio. (Ya Tuhan Kakek, Nenek, Bapak, dan Ibu kami ... Tuhan yang menjadikan dunia dan segala isinya).

Kata ikonik bu'u artinya "pergi". Kata $b u$ 'u sebagai simbol menunjukkan bahwa pemantra menghendaki agar penyakit COVID-19 yang membahayakan manusia, baik yang berasal dari iblis, binatang, atau makhluk lainnya segera pergi ke tempat di mana penyakit tersebut berasal agar tidak lagi mengganggu kehidupan manusia. Perhatikan kutipan berikut.

Sitat ilbis bu'u ngajuk pulei jalbelkab ngan penyakit tih tunah manusio bu'u goih penyakit neh maupun penyakit de mese binatakng wadayeh ngan wapiit. (Jika penyakit ini berasal dari ilbis, pergilah penyakit ini ke pulau Jalbelkab, jika 
penyakit ini adalah buatan manusia, ataupun disebabkan oleh binatang pergilah juga ke pulau Jalbelkab).

Pulau Jalbelkab adalah simbol yang digunakan untuk menjelaskan suatu tempat pembuangan dan sekaligus sebagai asal segala macam hal yang kurang baik, seperti penyakit dan malapetaka yang mengancam kehidupan manusia, termasuk COVID-19.

\section{Mantriks dan Model Mantra Tolak Bala Dayak Kerambai}

Menurut Riffaterre (1978) matriks adalah kata yang menjadi kunci penafsiran puisi atau mantra yang telah dikonkretisasi dan kata tersebut berhubungan dengan kata lainnya yang ada dalam puisi atau mantra dan menjadi pusatnya. Matriks berupa suatu tuturan minmal dan harfiah yang selanjutnya ditransformasikan menjadi parafase yang lebih panjang. Matriks tidak terdapat dalam teks, tetapi teraktualisasikan melalui model yang diungkapkan dalam bentuk kiasan. Model yang akan menentukan bentuk varian atau pengembangan yang akan muncul dalam teks.

Masalah pokok dalam mantra Tolak Bala Dayak Kerambai adalah tolak bala dunia COVID-19 togih mulai jaji penyakit tanau nganbu midunio yang artinya menolak penyebab awal terjadinya penyakit COVID-19. Kata yang berekuivalensi dengan masalah pokok tersebut meliputi; (1) tabi'i Tompau dan (2) puleu Jalbelkab. Mantra ini mencitrakan adanya hubungan kedekatan antara manusia dengan Sang Pencipta yang secara eksplisit disebutkan di dalam mantra. Kata tabi 'i Tompau yang dijumpai pada awal dan pada akhir mantra. Kata tersebut menunjukkan menyampaikan permohonannya kepada Tuhan sebagai penentu segala hal. Kalimat dalam mantra tersebut mengandung nilai religius yang berfungsi untuk memohon penyertaan Tuhan agar tidak terkena COVID-19 dan penyakit tersebut dijauhkan dari kampungnya.
Puleu Jalbelkab adalah nama pulau yang diyakini sebagai tempat berasalnya segala jenis penyakit. Oleh sebab itu pemantra mengusir segala macam penyakit, termasuk COVID-19 untuk pergi atau pulang kembali ke Puleu Jalbelkab sebagai tempat asalnya agar tidak mengganggu kehidupan Dayak Kerambai.

Hasil penelitian yang dilakukan oleh Kahfi, Kembong, dan Sultan (2021) menunjukkan bahwa matriks dalam mantra yang ditelitinya berupa penolak bala dan keberkahan dan model dalam penelitian tersebut adalah permohonan agar terhindar dari bala bencana. Hal yang sama ditemukan juga dalam penelitian terhadap mantra tolak bala Dayak Kerambai bahwa matriks berupa penolakan terhadap COVID-19 sebagai bala bencana dan model berupa permohonan kepada Tuhan agar COVID-19 dijauhkan, diusir, dan dilenyapkan dari kampung mereka dan dibuang ke pulau Jalbelkab.

\section{Hipogram Mantra Tolak Bala Dayak Kerambai}

Hipogram adalah teks yang menjadi latar penciptaan sebuah karya (Riffaterre, 1978). Teks yang dimaksud tidak hanya berupa tulisan, tetapi juga cerita lisan, adat, tatanan masyarakat, dan bahkan dunia ini adalah teks. Berkaitan dengan hipogram tersebut Ratih (2016) menjelaskan bahwa hipogram yang menjadi landasan bagi penciptaan karya yang baru, mungkin dipatuhi atau mungkin juga disimpangi oleh pengarang. Selanjutnya Ratih (2016) juga menjelaskan konsep Riffaterre tentang dua jenis hipogram, yakni hipogram potensial dan hipogram aktual. Hipogram potensial tidak tereksplisitkan di dalam teks, tetapi harus diabstraksikan dari teks. Adapun hipogram aktual berupa teks nyata, kata, kalimat, peribahasaa atau seluruh teks.

Hipogram dalam mantra tolak bala Dayak Kerambai dilatarbelakangi oleh adanya tradisi tolak bala yang dilakukan komunitas Dayak Kerambai sejak zaman dahulu untuk mengusir atau memulangkan kembali segala macam bencana, malapetaka, dan penyakit termasuk virus COVID-19 ke Puleu Jalbelkab melalui bantuan Tompau (Tuhan). 
Mantra tersebut menunjukkan adanya hubungan manusia dengan Tuhan. Hubungan yang dimaksud yaitu dalam konteks ritual adat budaya yang dikolaborasikan dengan doa-doa yang dipanjatkan kepada Tuhan yang dikenal dengan sebutan Tompau Babuk, Tompau Tayuk, Tompau Omang, Tompau Oyang ngan Tompau togih mula jaji dunia. Sebutan tersebut mengimplikasikan bahwa terdapat hubungan antara pemantra dengan Tuhan sebagai pencipta dunia. Melalui mantra tersebut pemantra yang mewakili komunitasnya memohon dan berharap agar Tompau melindungi mereka dari COVID-19 yang mengancam hidup mereka dan supaya COVID-19 diusir atau dilenyapkan dari kampung mereka.

\section{Pembacaan Heuristik dan Hermeneutik Mantra Tolak Bala Dayak Hibun}

Rusmana (2014) menyatakan bahwa pembacaan heuristik merupakan pembacaan berdasarkan struktur kebahasaan atau disebut dengan pembacaan semiotik tingkat pertama. Pembacaan heuristik dapat berupa penerangan bagian bagian dari sebuah karya sastra secara berurutan. Pembacaan hermeneutik yaitu pembacaan karya sastra berdasarkan sistem semiotik tingkat kedua. Pembacaan hermeneutik merupakan pembacaan ulang sesudah pembacaan heuristik dengan memberikan konvensi sastranya

Kajian terhadap mantra tolak bala Komunitas Dayak Hibun bertujuan untuk memohon berkat dan perlindungan Tuhan atas kendaraan (mobil) yang digunakan untuk melaksanakan tugas dan kegiatan sehari-hari. Mantra ini terdiri atas mantra "mentah" dan mantra "masak". Mantra "mentah" adalah mantra yang diucapkan pemantra saat ayam sebagai satu di antara sesaji yang digunakan belum disembelih. Mantra "masak" adalah mantra yang diucapkan pepomang pada saat ayam sebagai bagian dari sesaji telah disembelih dan telah dimasak. Mantra "mentah" terdiri atas 22 bait (bagian) dan mantra "masak" terdiri atas 4 bagian. Perhatikan kutipan bait pertama mantra "mentah" berikut ini.
Nyaik, dukah, tahuh, mpak, himuh, nim, ju... Ko ngasap ngambur kone bohah kuning, bohah slama'k to nyok kua, mbibu nyompuk kone mobel motan kone gok badi gok banoh, Motan kone goh munt sitan munt bolis, bohuko bobando bontek betibok betingkong baaa.... Honuang kone mobel to, kone slamat baek koyuh pomang go mobel to a. (Satu, dua, tiga, empat, lima, enam, tujuh... saya menabur beras kuning, beras keselamatan, untuk memberkati mobil ini, membuang segala hal yang buruk, hantu, setan, yang mengintai mobil ini. Barang-barang yang disajikan ini digunakan untuk memberkati mobil ini).

Beras kuning merupakan satu diantara sesaji yang digunakan pemantra, yang dipercayai sebagai beras pembawa keselamatan yang mampu menjauhkan sesorang dari marabahaya. Selain beras kuning, pemantra juga menggunakan asap gaharu dan bunga sebagai sesaji. Perhatikan kutipan bait kedua berikut ini. Asak garu nado ko manu, asak mimo nadu ko nyondo kone gok abae ponompa datok senggiang singkalot nado ko ntek bibuk ko ngonoang kusuk nginyok baa. (Asap gaharu dan asap bunga kuutus untuk menyampaikan kepada Penompa (Tuhan) supaya menerima sesajen yang disedia-kan ini).

Pada bait kedua ini, pemantra memohon kepada Penompa (Tuhan) dengan menggunakan asap gaharu dan asap bunga sebagai bahan persembahan dengan tujuan agar Penompa (Tuhan) berkenan mengabulkan harapan dan permohonan pemantra, yakni memberkati mobil dan pemilik mobil yang sedang didoakan. Perhatikan kutipan berikut ini.

Pomang mbaco kone mobel nto lek ko $a$, motan kone gok odoh munt sitan, munt bolis, mut ponompang bak mohi bangacau bakiko betek betibok ko a. Mobel gok Joe dimok to, slamat baek panjang umoh panjang nyawa, koeh nyo bah mban kone gok mobel, kidoh nopak kone gok balo kohomo, kidoh nopak kone usok ngaso, kone badan kone bako tompo senggolo (Pembacaan mantra ini bertujuan untuk mengusir hantu, setan, dan segala makhluk halus lainnya supaya pulang ke tempat asalnya. Jangan tinggal di dalam mobil 
ini, supaya pemiliknya selamat jiwa dan raganya, tidak mendapat musibah. Siapa saja yang menggunakan mobil ini tidak mendapat musibah, tidak mengalami sakit pada seluruh tubuhnya).

Pada bait ketiga ini pemantra membersihkan mobil dari ganguan berbagai macam hal seperti hantu, setan, dan makhluk halus lainnya serta mengusir berbagai macam penyakit dan marabahaya.

Pada bait berikutnya, bukan hanya mobil yang didoakan, tetapi juga kerukunan dalam hidup berkeluarga dan supaya rumah yang ditinggali diberi perlindungan oleh Penompa (Tuhan). Perhatikan kutipan berikut. Golek dukah tahuh mpak himuh nin ju. Ko tomoh to bohah kuning bohah slamat, slamat baek, slamat midiek, slamat ngan asang midiek, asang nyawo pemodiek, slamat baek gok homing lawang tompak ponai asok cahong ponai pendudok. (Satu, dua, tiga, empat, lima, enam, tujuh. Akumenabur beras kuning, beras selamat, supaya selamat dalam kehidupan, sehat, rukun dalam rumah tangga, maupun tempat tinggal).

Dalam mantra ini ayam yang masih hidup digunakan untuk mengusir berbagai hal buruk dengan nengibaskan sayapnya pada mobil yang sedang didoakan. Paruh ayam tersebut diolesi dengan minyak kunyit. Perhatikan kutipan berikut. Golek, dukah, tahuh, mpak, himuh nim, ju.... Banyak keluai natai banyak buok lobok, kae suoh nyo makai nginyok han nyok bohongkah mpuong kae suoh nyok makai nginyok kocik seniang ayam basar sengiang manok basak makan nasi ujong pinggan makan bohah ujong coh opan tangkok mo kontik dalan kojomo kontik ikam usok mo kontik nyawoh. Nyok mo pitak, nyok mo mihis inok, nyok mo nigang omuh, nigang haus, sigik oguh. Uhah tigik kotah pantas sigih tobah. Ohai kasing lopak duwah, tamuh lopak botang. (satu, dua, tiga, empat, lima, enam, tujuh. Banyak burung keruak di sawah tidak pernah digunakan orang untuk memberangkatkan kalian (hantu, setan), besar atau kecil tetap menggunakan ayam. Ayam besar makan nasi di piring, makan beras di penampik, setengah dadanya sebesar talanan, kakinya besar sekali, dadanya sebesar kuali besar (Bahasa mantra untuk makhluk halus yang kecil dikatakan besar). Untuk kamu belanja, untuk kamu pengeras badan, untuk buang haus. Humus tebal, duri dalam daging, cacing dalam batang habis terbuang dikibas ayam atau diibaratkan semua sial dan penyakit sudah terbuang).

Dalam hal ini sayap ayam yang dikibaskan sebagai simbol yang digunakan untuk menerbangkan atau membuang segala macam bentuk penyakit, sial, dan makhluk halus lainnya yang dapat mengganggu mobil atau siapa saja yang menggunakan mobil tersebut. Bagaimanapun, pemantra tetap akan menggunakan ayam saat membacakan mantra, bukan burung, meskipun ayam yang digunakan itu kecil tubuhnya. Perhatikan kutipan bait kesepuluh berikut ini. Amak jelama kmidiek jelamak ngasang sidik selamak kone badan kone bako kone mpun senggolo, ko kosan gok pisang tembawang botuh nting tapang gah. Ading gandong tapong hayo biso kone tukok bobo hoyang jiho ko nto momang maco mbi bonyo. Obu ko mae mioh motan konegok tohobing tohupong, tangkoh dokit sebadan bako senggiang bos ito bah, Kae nyok ngacau kae nyok ngkiko kone onak usokjelomoh han ntoput dopak, ma ko nyok tihing, kone gok johan. (Penyakit sekecil apapun dalam tubuh dapat disembuhkan. Saya menebas pisang Ketapang di tembawang (artinya membuang segala penyakit ke tembawang). Semoga apa yang saya ucapkan pada ritual ini mujarab. Sudah dibuang jauh-jauh sial dan penyakit ke hutan rimba, ke tebing jurang. Tidak akan mengganggu anak manusia saat berjumpa di persimpangan jalan). Kutipan ini menunjukkan bahwa pemantra mengucapkan kata yang sama secara berulangulang dengan tujuan untuk memberikan kekuatan dan menjauhkan orang yang didoakan dari marabahaya dan penyakit. Pemantra merintahkan makhluk halus agar tidak mengganggu manusia dan tidak mendiami setiap persimpangan jalan.

Pada bait kesebelas hingga bait ketujuh belas, pemantra membuang jauh-jauh penyakit dan kesialan ke hutan rimba dan ke sungai agar pada saat mengendari mobil terhindar dari 
malapetaka, dijauhkan dari musibah, dan dijauhkan dari orang-orang yang berkata tidak baik. Pemantra memohon agar manusia dijauhkan dari sifat jahat atau buruk, selamat dalam kehidupan sehari-hari, dijauhkan dari bencana dan marabahaya. Pemantra berharap mantra yang diucapkannya mujarab dengan memasrahkan semua permohonannya kepada Penompa (Tuhan). Perhatikan kutipan berikut ini. Bisoh tukok bobo hoyang iho ko nto motan ohaan ningkang miah minto mooh tiban kone gok balo hohomo. Motan kone gok usok maraso to ahh... kae nyok nyongkie, kae nyok mpiek to a, kone mobel to, mosik lok ko nyopak, mak mosik lek ko mibu nyopu ko mang miau nyingkang nyin... mioh minto mindoh motan kone tohun biek tohun pohis, dakoh dokis mosik nyok buok. (Mujarablah semua ucapanku untuk membuang, memindahkan segala marabahaya, membuang sial jangan sampai tinggal di mobil ini. Semua kubuang, kusingkirkan, kupindahkan ke hutan balantara. Semua yang kotor kukibaskan).

Pada bait kedua puluh hingga kedua puluh dua ditunjukkan penggunaan minyak kuning yang berfungsi untuk memberikan keselamatan dengan cara mengoleskannya pada bagian stir, pintu, tempat duduk, mesin, dan ban mobil, Perhatikan kutipan berikut. Golek dukah tahuh mpak himuh nin ju.... Nginyu ntomu kone bangku to kae nyok mpiek, kae nyok ngacau, kae nyok ngkiko kae nyok ngono kejoho, ko nginyok kone gigin, kae nyok ngapiek kone gok kojo kae ngapiek kone gok tongan. Slamat baek gok nyo mban kone mobel kidoh ndopak. (Satu dua tiga empat lima enam tujuh. Ini saya mengoleskan minyak kunyit ke kursi supaya tidak diganggu, tidak terkena bahaya. Ini saya mengoleskan minyak kunyit ke pintu, jangan sampai terjepit kaki terjepit tanggan. Selamat orang yang membawa mobil ini, jangan sampai mendapat marabahaya). Mantra "masak" terdiri atas lima bait, merupakan mantra yang diucapkan setelah ayam yang dikibaskan sayapnya pada mantra "mentah", disembelih dan dimasak. Pada hakikatnya mantra "masak" ditujukan menghaturkan sesajian sebagai ungkapan rasa syukur kepada Penompa
(Tuhan) atas berkat yang diterima dan juga untuk memberi makan hantu, setan, iblis, dan makhluk halus lainnya agar tidak mengganggu kehidupan manusia. Perhatikan kutipan berikut. Golek dukoh tahuh mpak himuh nim ju.... It sik nto nutu sok yank podi bohah ngkayau ngkadoh ntah osi nungu sok pengah ohmo nuk tauhbohi babae ko no sumpau abae penompo munyok mpant makant kone diyent dimokso do segalo nyuhok nyomoh munyok kone mpan makant munyok kone tehon aedap kone dimokso do segalo kone anyong siyok kone gatu biko negaham kone ga tu wok gayung ko munyok kidoh pengko sinado ko ntilek ntibok honung pengodi penyalant tangun tanant ko to ngojan kone diyent dimokso dosegalo odoh kone upoh lalo hupoh laloh den siyan klanan kupoh laloh ja rupai gadai upoh laloh diyent ngingak ngatoh kone asong kone nyawo kone badan kone bako kone mpose ngolo kone Jo dimoksod o segalo kidoh nopak kone pehungo onu kidoh nopak lotik tompo kelimpah keliseh sik tukok bobo hoyong jiho nyok kelimpah keliseh kesiatangun tanan pengodi penyalant kone Jo dimok pemunyok mpan makan pemunyok teh onae dap diyentn ado ko ngingak ngatoh asong nyowo ngohint yok bis nyowo odi diyent ngatoh ngagam kone pemi die pengasong selamak baek kidoh nopak kone ga a memalo kehomo kidoh nopak kone usok benaso kone badan kone bako oko nto hak nyono ngojan nyono kone dimok sodo segalo. (Satu, dua, tiga, empat, lima, enam tujuh... Matahari terbit saya memanggil roh padi dan menyembah Tuhan Yang Mahakuasa, saya menghaturkan persembahan kepada Tuhan agar sudi kiranya menerimanya. Mohon perlindungan-Mu untuk keluarga ini agar selamat kalau dia pergi kemanamana, tidak mendapat bahaya. Mohon Tuhan menjaga mereka. Saya memanggil Tuhan untuk menerima berbagai makanan yang dipersembahkan berupa ayam, nasi, garam, tuak, dan sayur. Kiranya Tuhan Yang Mahakuasa mengatur rumah tangga mereka, melindungi mereka dari sakit penyakit dan panas badan). Inti permohonan yang disampaikan dalam mantra 'masak' bait pertama sampai dengan bait kelima adalah mengundang Ponompa (Tuhan) agar sudi kiranya menerima sesajian yang dipersembahkan sebagai ungkapan rasa syukur 
keluarga atas penyertaan Penompa (Tuhan) dalam kehidupan mereka. Selain itu, pemantra juga mengundang para hantu, setan, iblis, dan makhluk halus lainnya untuk menyantap sesaji yang secara khusus sudah juga dipersiapkan untuk mereka agar mereka tidak mendatangkan penyakit, musibah, dan marabahaya bagi keluarga yang sedang melakukan ritual tolak bala tersebut, terutama mobil yang mereka gunakan tidak mendatangkan malapetaka bagi mereka dan bagi siapa saja yang menggunakan kendaraan tersebut.

\section{Mantriks dan Model Mantra Tolak Bala Dayak Hibun}

Kata kunci dari serangkaian teks disebut matriks. Menurut Ratih (2016) matriks ialah konsep abstrak yang tidak pernah teraktualisasi dan tidak muncul dalam teks. Matriks dapat berupa kata, frase, klausa atau kalimat sederhana. Model adalah pembatas derivasi tersebut sebagai bentuk aktualisasi dari matriks yang dapat berupa kata atau kalimat tertentu. Model kemudian diekspansikan ke dalam varian-varian sehingga susunan sebuah teks menjadi utuh.

Masalah pokok dalam mantra tolak bala Dayak Hibun ini adalah keluarga yang melaksanakan ritual memohon agar kendaraan (mobil) yang mereka miliki diberkati dan terhindar dari kecelakaan dan marabaya. Katakata yang menjadi kunci untuk memahami mantra ini adalah bohah kuning, asak garu, pomang mbaco, nyu ntomu, senggiang bosi, tembawang, abai dato ponompo, pitnmane, peho teh sengkarok, dan simpok bangkow. Katakata tersebut berperan untuk menimbulkan suasana religius dan efek magis dalam mantra.

Frasa bohah kuning (beras kuning) yang terdapat pada bait pertama menunjukkan keyakinan kepada beras kuning sebagai beras memberikan keselamatan. Penggunaan beras tersebut ditaburkan pada tempat atau benda-benda yang ingin diberkati.
Frasa asak garu (asap garu) hanya muncul pada bait kedua di mantra ini. Namun, demikian frasa ini merupakan aktualisasi dari matriks Asak garu adalah asap garu yang dipercayai sebagai media penyampaian kepada Tuhan untuk melihat dan menyantap sesajian yang sudah disiapkan dalam ritual tolak bala tersebut.

Frasa pomang mbaco (pembacaan mantra) menunjukkan bahwa seizin para leluhur, mantra tersebut digunakan untuk memberkati mobil keluarga yang melaksanakan ritual tolak bala. Tujuannya untuk mengusir hantu, setan, iblis, dan makhluk halus lainnya yang mendiami mobil agar pergi ke tempat asalnya sehingga pemilik dan siapa saja yang menggunakan mobil tersebut diberikan keselamatan dan terhindar dari kecelakaan.

Frasa nyu ntomu (minyak kuning) yang hanya muncul pada bait kelima dalam mantra ini. Kata nyun tomu bermakna mengoleskan minyak kuning ke mobil atau peralatan lainnya. Minyak kuning diyakini sebagai pembawa keselamatan, berfungsi melindungi orang atau benda yang didoakan dari penyakit dan marabahaya.

Frasa senggiang bosi (asal atau semangat besi) terdapat pada bait ketujuh dan kesepuluh. Frasa senggiang bosi merupakan simbol yang digunakan untuk menunjukkan roh yang kuat, keras seperti besi yang mampu bertahan dalam keadaan apapun sehingga dijauhkan dari setan ataupun hantu pengganggu pada setiap persimpangan jalan. Frasa senggiang bosi mengandung nilai magis yang berfungsi mempengaruhi makhluk halus agar mau melaksanakan apa yang diinginkan pemantra.

Kata tembawang terdapat pada bait ketiga belas. Kata tembawang bermakna kawasan yang luas sebagai warisan leluhur yang menjadi milik bersama antarkeluarga yang ditanami dengan beraneka macam pohon buahbuahan seperti durian, langsat, rambutan, dan sebagainya. Kata tembawang dalam mantra ini merupakan simbol yang menunjukkan suatu tempat yang sepi yang ditumbuhi berbagai macam jenis pohon buah-buahan yang 
digunakan pemantra untuk membuang berbagai macam penyakit yang berbahaya supaya tidak mengenai dan mengganggu manusia.

Frasa abai dato penompa (Tuhan) yang terdapat pada bait keenam belas menunjukkan sikap penyerahan diri kepada Tuhan. Mantra religius ini berfungsi untuk memohon penyertaan Tuhan agar mimpi buruk yang dialami tidak membawa musibah.

Frasa pitn mane (air mandi) merupakan air yang digunakan untuk mandi berisi tujuh macam bunga. Dalam ritual mantra tolak bala ini air mandi yang berisi tujuh macam bunga ini diyakini dapat membersihkan dan mengusir hal-hal yang tidak baik.

Frasa pehoteh sengkarok adalah padi ketan yang dioseng yang berfungsi sebagai pembawa keselamatan dalam ritual tolak bala tersebut. Frasa simpok bangkow adalah mangkuk atau piring yang berisi abu dan bara api yang digunakan untuk membakar kayu gaharu atau kemenyan dan bunga selasih ladang. Hal tersebut menimbulkan aroma wewangian yang dipersembahkan kepada Penompa (Tuhan Yang Mahakuasa).

Kata ncahu adalah istilah yang digunakan untuk menamai sesajian yang berisi campuran bulu ayam, kuku ayam, paruh ayam, nasi, garam, dan tuak yang secara khusus diperuntukkan sebagai makanan bagi hantu, setan, iblis, dan makhluk halus lainnya.

Matrik dan model yang ada dalam mantra tolak bala ini menunjukkan upaya yang dilakukan pemantra untuk menguasai keadaan sehingga baik keluarga yang didoakan maupun pemantra tidak tertimpa penyakit yang mengancam keselamatan dan dijauhkan dari marabahaya. Selain itu pemantra juga meminta perlindungan dan berkat sehingga melalui ritual tolak bala ini semua keinginan dan permohonan keluarga dikabulkan oleh Penompa (Tuhan Yang Mahakuasa).

\section{Hipogram Mantra Tolak Bala Dayak Hibun}

Mantra tolak bala Dayak Hibun menunjukkan adanya hubungan yang erat antara manusia dengan Penompa (Tuhan). Hubungan manusia dengan Tuhan dimanifestasikan dalam bentuk doa, permohonan, dan pengharapan agar kendaraan (mobil) keluarga yang didoakan dan siapa saja yang menggunakan mobil tersebut beroleh perlindungan dan keselamatan dari Penompa (Tuhan) serta terhindar dari marabahaya. Ritual tolak bala merupakan satu di antara sekian banyak cara manusia untuk berhubungan dengan Penompa (Tuhan). Hubungan tersebut ditandai dengan rasa syukur yang diungkapkan dalam bentuk persembahan berupa daging ayam yang dicencang halus dan dicampur dengan garam.

\section{Pembacaan Heuristik dan Hermeneutik Mantra Tolak Bala Dayak Simpakng}

Mantra tolak bala Dayak Simpakng yang dianalisis terdiri dari lima bait. Mantra tolak bala ini ditujukan untuk menjauhkan manusia dari segala penyakit, menyembuhkan manusia dari berbagai penyakit yang dideritanya, dan menghindari marabahaya. Mantra ini digunakan untuk memperoleh pertolongan dan perlindungan dari Tuhan.

Seperti mantra dalam komunitas Dayak pada umumnya, pemantra memulainya dengan menyebutkan angka "sa, dua, tiga, ampat, lima, nam, tujoh, sa dua tiga ampat" (satu dua tiga empat lima enam tujuh, satu, dua, tiga, empat). Penyebutan urutan angka tersebut sebagai simbol yang menandakan bahwa mantra atau bagian mantra itu segera akan dimulai. Angka-angka tersebut diucapkan sebagai simbol pemberitahuan yang ditujukan kepada Tuhan, setan, iblis, makhluk halus lainnya, dan komunitas yang menyelenggarakan ritual tolak bala agar menaruh perhatian pada mantra yang sedang diucapkan. Perhatikan kutipan bait pertama berikut. Sa, dua, tiga, ampat, lima, nam, tujoh, sa, dua, tiga, ampat. Motih onu pojam, pojam tengolam, yang jat jakat cicek cemar bunto dano, rawan ropang romang menyasat. Narobit motih onu midop, sa, dua, tiga, ampat, lima, nam, tujoh, (Satu, dua, tiga, empat, lima, enam, tujuh, satu, dua, tiga, empat. Matahari mati, mati tenggelam, yang jahat-jahat yang menjijikan, yang tercemar, yang busuk, tenggelam dalam danau, tertombak, dan tersesat dalam awan. Terbitlah matahari, satu, dua, tiga, empat, lima, enam, tujuh). 
Kutipan tersebut menunjukkan adanya penyerahan diri kepada Tuhan dalam menjalani hidup sehari-hari, berupa perbuatan baik maupun buruk. Perbuatan yang buruk hendaknya tenggelam seiring dengan terbenamnya matahari. Dengan terbitnya matahari, pemantra berharap agar pada hari yang baru kehidupan mereka tetap aman dan dijauhkan dari marabahaya. Perhatikan kutipan bait kedua berikut ini. $\mathrm{Sa}$, dua, tiga, ampat, motih onu trobit, trobit yang bagas. Pisang komang lantang, tabuh lulong anak, lunye menyabe bonang. Tarok bringin tali di samang benua panyang, di ujong bentangan lanok, motih onu trobit yang baek bagas. Ngelalong pake ngemotong, ujong nak tumang tamak riam, inang nak tulah, inang nak busong (Satu, dua. tiga, empat, matahari terbit dengan cerahnya, terbit dengan indahnya. Anak pisang yang ditabur dan baru tumbuh, dibalut dengan benang. Tali disimpan di beringin benua panjang, di ujung bentangan seperti air yang tenang. Matahari terbit dengan cerahnya, melintasi dengan memotong, ujungnya akan tumbang dan masuk ke dalam riam, jangan mau tulah, jangan mau tulah).

Kutipan tersebut menunjukkan adanya harapan dalam kehidupan. Harapan itu disimbolkan dengan matahari yang terbit dengan cerah. Maknanya adalah hari-hari yang dilalui dalam keadaan aman, kondusif, dan dijauhkan dari jenis penyakit yang membahayakan. Manusia diingatkan agar tetap menabur kebaikan, walaupun hanya perbuatan kecil, namun dapat membantu dan berguna bagi kehidupan orang lain. Perhatikan kutipan bait ketiga. Oko nak ntusa duata manok, nak nturun sengiang ayam, sengkuang ngada kiompok, kiompok ngada kadidih, kadidih ngada $k a$ sangiang, sangiang ngada ka manok, di langit susun tujoh di awan tilap onap. (Saya memohon kepada Tuhan, agar menurunkan segalanya untuk ayam, buah sengkuang memberi kiompok, kiompok memberi kadidih, kadidih memberi sangiang, sangiang memberi ke ayam, di langit susun tujuh, di awan tidak terlihat).
Kutipan tersebut menunjukkan permohonan pemantra kepada duata (Tuhan). Wujud permohonan itu adalah agar Tuhan menurunkan makan kepada makhluk hidup ciptaan-Nya. Menurunkan rezeki berupa makanan sehingga sesama makhluk hidup dapat saling membantu dan saling berbagi terutama kepada mereka yang membutuhkan bantuan. Perhatikan kutipan bait keempat. Manong donang lokar, ayam lontek kepayang, baringis bintang banyak, bentolok bulan muda, yo mentolok lam pemasok, yo ngoram pucok cangam, mocek ringgis sonnek, notas turo basah. (Burung donang lokar, ayam lontek kepayang, baringis bintang banyak, bertelur bulan muda. Dia bertelur dalam pemasok (tempat ayam bertelur), dia mengeram di pohon cangam (sejinis bumbu untuk masak daging), mengambil linggis kecil, menetas telur basah). Burung yang dimaksud dalam kutipan bait keempat ini adalah burung yang diyakini sebagai penanda yang membawa kabar baik atau sebaliknya. Masyarakat Dayak Simpakng meyakini hal itu. Oleh sebab itu, saat ritual tolak bala burung donang lokar disebut dalam pembacaan mantra. Perhatikan kutipan kelima berikut ini.

Tanurun ka tonah manomaga ka urat ano mawang, makan remukut ujong capan, makan podi ulok gantang, makan nyolek ulok kranyang minum mare plimang. (Diturunkan ke tanah manomaga ke akar tanaman yang hendak mekar. Makan lemukut di ujung capan, makan padi di dalam gantang. Makan dicolet depan keranjang, minum di depan rumah). Kutipan tersebut menunjukkan sikap kebersamaan yang ditujukkan dalam ritual tolak bala. Pemantra mengharapkan agar kekompakan keluarga dan warga kampung untuk menjaga suasana kampung. Selain itu, pada saat berlangsungnya ritual tolak bala semua anggota keluarga beraktivitas di dalam rumah. Dengan demikian diharapkan semua orang dijauhkan dan terhindar dari berbagai jenis penyakit yang membahayakan. 
Mantriks dan Model Mantra Tolak Bala Dayak Simpakng

Masalah pokok pada mantra tolak bala Dayak Simpakng ini adalah keinginan warga kampung untuk memperoleh keselamatan dan dijauhkan dari berbagai penyakit yang membahayakan. Kata-kata yang menjadi kunci untuk memahami mantra ini adalah motih onu pojam, motih onu trobit, dan ntusa duata. Frasa tersebut merupakan ungkapan yang masing-masing berperan untuk menimbulkan efek magis dalam mantra.

Frasa motih onu pojam (matahari terbenam) menunjukkan ditenggelamkannya berbagai hal buruk dalam kehidupan manusia bersamaan dengan terbenanmnya matahari. Frasa motih onu trobit (matahari terbit) melambangkan kehidupan sehari-hari yang baik, yang tidak mengalami suatu musibah atapun bencana. Pada ritual bebantan (tolak bala) ini, pemantra mengungkapan semua keinginan dan harapannya agar warga kampung terhindari dari suatu keadaan yang buruk, terhindar dari berbagai penyakit yang membahayakan.

Frasa ntusa duata bermakna permohonan kepada duata (Tuhan). Permohonan tersebut berupa harapan agar semua makhluk hidup diberikan penghidupan yang baik, aman, tenteram, dan terhindar dari berbagai penyakit yang berbahaya. Selain itu, berlimpah rezeki dan makanan.

Hipogram seperti dead landscape yang mengacu kepada realitas yang lain dan keberadaannya harus disimpulkan sendiri oleh pembaca Lantowa (2017) Seperti yang dikatakan Lantowa, hipogram dalam mantra tolak bala Dayak Simpakng adalah ritual turuntemurun yang telah dilakukan oleh nenek moyang komunitas ini saat mereka menghadapi bencana, marabahaya, dan penyakit. Mantra ini memperlihatkan adanya hubungan yang erat antara manusia dengan duata (Tuhan). Hubungan spiritual ini merupakan hubungan yang istimewa sebab pada hakikatnya manusia adalah ciptaan.
Hubungan manusia dengan Tuhan dalam mantra bebantan dilakukan dengan mendekatkan diri dengan memohon dan meminta keselamatan. Mantra bebantan merupakan mantra yang pertama kali digunakan ketika menghadapi situasi dan kondisi yang menimpa manusia berupa wabah penyakit.

Selain itu, mantra tersebut juga tidak dapat digunakan sembarangan orang, karena hanya orang tertentu yang dapat menggunakan mantra tersebut. Mantra ini digunakan pemantra dengan memohon kepada Tuhan untuk dilindungi dan dijauhkan dari berbagai penyakit berbahaya dan hal-hal yang mengganggu manusia. Pelaksanaan ritual mantra ini dilakukan dalam satu hari, dari pagi hingga malam hari. Ritual tolak bala ini hanya dapat disaksikan oleh orang-orang tertentu, seperti ketua adat, tokoh masyarakat, dan pemuka agama.

\section{Simpulan}

Secara heuristik dan hermeneutik, mantra tolak bala komunitas Dayak merupakan sarana komunikasi yang berisi permohonan kepada Tuhan agar mereka terhindar dari virus COVID-19, bencana, malapetaka, dan hal-hal buruk yang menggangu kehidupan manusia.

Matriks dalam mantra tidak hadir secara langsung dalam teks mantra, model tampil sebagai aktualisasi matriks. Makna mantra menjadi lebih terfokus melalui penetuan model.

Hipogram dalam mantra tolak bala merupakan hipogram potensial yang didasarkan pada realita bahwa penggunaan mantra tolak bala telah menjadi ritual yang sakral dan turuntemurun yang mereka yakini dan percayai dapat melindungi mereka dari ancaman marabahaya, malapetaka, dan sakit-penyakit termasuk COVID-19. Hal tersebut tampak pada kesamaan pola sasaran pada ritual tolak bala yang menghendaki agar Tuhan melindungi mereka, sehingga makhluk halus dan hal-hal buruk tidak mengganggu hidup mereka. Kesamaan lainnya tampak melalui penyebutan kata bilangan 
pada saat memulai membaca setiap bagian dari mantra. Komunitas ini meyakini bahwa mantra tolak bala nerupakan doa yang memiliki kekuatan untuk mendapatkan keselamatan dan perlindungan dari Tuhan. Bagi komunitas Dayak, mantra tolak bala berfungsi sebagai media komunikasi untuk mengusir makhluk halus yang mendatangkan penyakit, bencana, marabahaya atau malapetaka. Kontribusi penelitian ini berupa rekomendasi kepada para peneliti lain yang tertarik untuk menggunakan kajian semiotik Riffaterre dalam mengkaji genre sastra yang berbentuk puisi, prosa, drama, maupun bentuk-bentuk komunikasi lainnya. Hasil penelitian ini dapat dijadikan sumber rujukan.

\section{Ucapan Terima Kasih}

Penulis berterima kasih kepada para informan, penutur mantra, dan para asisten lapangan yang telah membantu dalam proses perekaman, pentranskripsian, dan penerjemahan teks mantra.

\section{Daftar Pustaka}

Al Fikri, M. F. dkk. (2019). Mantra Petapa Alas Purwo: Kajian Semiotika Riffaterre. Jurnal Semiotika, 20 (2), 108-119. https://jurnal. unej.ac.id/index

Alloy et al. (2008). Mozaik Dayak Keberagaman Subsuku dan Bahasa Dayak. Pontianak: Institut Dayakologi.

Andalas, E. F., \& Sulistyorini. (2017). Sastra Lisan. Madani.

Chofeer, A. J. L., \& Darmawan, A. R. (2021). Tradisi Tolak Bala Sebagai Adaptasi Masyarakat Dayak Desa Umin Dalam Menghadapi Pandemi Di Kabupaten Sintang. Habitus: Jurnal Pendidikan Sosiologi dan Antropologi, 5 (1), 53-68.

Darmadi, H. (2016). Dayak Asal-Usul dan Penyebarannya. Sosial Horizon:Jurnal Pendidikan Sosial, 3(2), 322-340. doi: http:// dx. doi.org/10.31571/sosial.v3i2.376.

Diana, J. (2018). Makna Puisi Pohon Peradaban Karya Dinullah Rayes Kajian Semiotika Riffaterre. Jurnal Pena Indonesia, 4(2), 173-188 http://journal.unesa.ac.id/
Faruk. (2012). Metode Penelitian Sastra, Sebuah Penjelajahan Awal. Pustaka Pelajar.

Frelians, P.P. \& Perbawaningsih, P. (2020). Media Sosial Ruang Dayak dalam Mereduksi Stigma Kebudayaan Dayak. Jurnal Ilmu Komunikasi, 18 (2), 181-193.

Hamidin, M. (2016). Bentuk, Fungsi, dan Makna Mantra Ritual Upacara Kamsambu Masyarakat Muna di Kecamatan Katobu Kabupaten Muna. Jurnal Bastra, 1(1).

Hamjen, W. (2015). Mengenal Tujuh Rumpun Suku Dayak di Pulau. Https://Www.Hipwee. Com/List/.

Hartata, A. (2010). Mantra Pengasihan (Rahasia Cinta dalam Klenik Jawa). Kreasi Wacana.

Hendro, Fanny, Topan Setiawan, D. S. (2021). Mempertahankan Eksis-tensi Tradisi Tungguk Tembakau melalui Media Sosial. Jurnal Ilmu Komunikasi, 19 (1), 78-92. https://doi.org/https://doi.org/10.31315/jik. v19i1.39

Hidayatullah, D. (2016). Struktur, Bentuk dan Fungsi Mantra Abal. Sirok Bastra, 4 (1). 161-174.

Kahfi, Kembong, \& Sultan. (2021). Analisis Semiotika Riffaterre pada Doangang Panjamabarakkang (Mantra Pertanian) Masyarakat Makassar di Kelurahan Bulukunyi Kabupaten Takalar. PANRITA: Jurnal Bahasa Dan Sastra Daerah Serta Pembelajarannya, 1(1), 22-29.

Kosasih. (2012). Dasar-Dasar Keterampilan Bersastra. Yrama Widya.

Lantowa, J. et al. (2017). Semiotika teori, Metode, dan Penerapannya dalam Penellitian Sastra. Deep publish.

Miles, M. B., \& Huberman, A. M. (1994). Qualitative Data Analysis. Sage Publication, Inc.

Moleong, L. J. (2017). Metode Penelitian Kualitatif. PT Remaja Rosdakarya.

Muhrotien, A. (2012). Rekonstruksi Identitas Dayak. TICI Publication. 
Nugraha, F. I. (2015). Mantra Bandung Bondowoso sebagai Tindak Tutur. Jurnal Ilmiah FONEMA: Jurnal Edukasi Bahasa dan Sastra Indonesia. https://doi.org/ 10.25139/ fn.v1i2.1177.

Nurjamilah, A. S. (2015). Mantra Pengasihan: Telaah Struktur, Konteks, Penuturan, dan Proses Pewarisannya. Riksa Bahasa.

Pradopo, R. D. (2011). Prinsip Prinsip Kritik Sastra. Pustaka Pelajar.

Ratih, R. (2013). Sajak “Tembang Rohani” Karya Zawawi Imron Kajian Semiotik Riffaterre. Kajian Linguistik Dan Sastr., 25 (1).

Ratih, R. (2016). Teori dan Aplikasi Semiotik Michael Riffaterre. Yogyakarta: Pustaka Pelajar bekerja sama dengan Masyarakat Poetika Indonesia.

Riffaterre, M. (1978). Semiotics of Poetry. Indiana University Press.

Riwut, T. (1993). Kalimantan Membangun Alam dan Kebudayaan. Tiga Wacana.

Rousseau, J. (1990). Central Borneo: Ethnic, Identity, and Social Life in Stratified Society. Cloredon Press.

Roy, P. (2012). Folk-Culture in Vedic Literaturs. Indian Streams Research Journal, 1. 1-5.

Rusmana, D. (2014). Filsafat Semiotika: Paradigma, Teori dan Metode Interpretasi Tanda dari Semiotika Struktural hingga Dekonstruksi Praktis. Pustaka Setia.
Santoso. (2004). "Tuhan, Kita Begitu Dekat: Semiotika Riffaterre." In T. dan U. Y. Christomy (Ed.), Semiotika Budaya. Pusat Penelitian Kemasyarakatan dan Budaya, Direktorat Riset dan Pengabdian Masyarakat, Universitas Indonesia.

Setiadi, D., \& Firdaus, A. (2018). Teks Mantra Embeung Beurang Seputar Kehamilan dan Kelahiran Bayi di Cidolog Kabupaten Sukabumi. Paramasastra: Jurnal Ilmiah Bahasa Sastra Dan Pembelajaran-nya. https://doi.org/https://doi.org/10.26740/ parama.v1i2.1489

Soedjijono, D. (2012). Bentuk dan Isi Mantra. Humaniora, Vol. 16 (2). 320-331.

Suwatno, E. (2012). Bentuk dan Isi Mantra. Jurnal Humaniora, Vol. 16, N, hlm. 320-331.

Taum, Y. Y. (2011). Studi Sastra Lisan: Sejarah, Teori, Metode, dan Pendekatan Disertai Contoh Penerapannya. Lamalera.

Teeuw, A. (1982). Khazanah Kesastraan Indonesia. Balai Pustaka.

Wardoyo, S. L. (2005). "Semiotic and Naration Structure." Universitas Diponegoro.

Yelle, R. A. (2003). Explaining Mantras: Ritual, Rhetoric, and the Dream of a Natural language in Hindu Tantra. In Explaining Mantras: Ritual, Rhetoric, and the Dream of a Natural Language in Hindu Tantra. https:// doi.org/ 10.4324 /9780203483381

Zoest, A. (1993). Semiotika: Tentang Tanda, Cara Kerjanya dan Apa yang Kita Lakukan Dengannya (Diindonesiakan Ani Soekawati). Yayasan Sumber Agung. 